\title{
Geophysical evidence for thrust faulting in the Carboniferous Antigonish-Mabou Subbasin, Nova Scotia"
}

\author{
P. Durling ${ }^{* *}$, P. Harvey ${ }^{2}$, and K. Howells ${ }^{3}$ \\ 'Geological Survey of Canada - Atlantic, Bedford Institute of Oceanography, \\ P.O. Box 1006, Dartmouth, Nova Scotia B2Y 4A2, Canada \\ ${ }^{2}$ Nova Scotia Department of Natural Resources, 1701 Hollis Street, \\ P.O. Box 698, Halifax, Nova Scotia B3J 2T9, Canada \\ ${ }^{3}$ Ken Howells Geoscience, 27 John Cross Drive, Dartmouth, Nova Scotia B2W 1X1, Canada
}

Date Received July 4, 1995

Date Accepted December 14, 1995

\begin{abstract}
Petroleum industry seismic reflection data and gravity profiles were used to interpret offshore and onshore geological structures in the Carboniferous Antigonish-Mabou Subbasin. Four seismic horizons were mapped, and the deepest (reflection ' $A$ '; near the base of the Windsor Group) was contoured to produce a time-structure map of the subbasin. The Antigonish-Mabou Subbasin is structurally complex and deepens to $2.8 \mathrm{~s}$ two-way time (5600 $\mathrm{m}$ ) in the north-central part of St. Georges Bay. It is substantially thinner onshore in the Antigonish (up to $1.0 \mathrm{~s}$; $2000 \mathrm{~m}$ ) and Mabou areas (up to $1.6 \mathrm{~s} ; 3200 \mathrm{~m}$ ).

The geophysical data have revealed more complex structures at depth than previously shown by surface mapping, boreholes or shallow penetration marine seismic profiling data. Within the subbasin, low angle thrusts and high angle strike-slip faults, salt structures and elevated basement blocks were mapped. Some faults have large throws (up to $3200 \mathrm{~m}$ ) and separate large uplifted basement blocks from deeper basinal areas. Movement on the faults is of post Windsor age. New evidence for thrusting is provided by: seismic data in southern St. Georges Bay; onshore seismic profiles in the Mull River area; and gravity profiles near Antigonish. Only one of these thrust faults has been mapped at the surface by previous workers in the area.

The thrust faults place Windsor Group and older rocks over basal Windsor Group reflections (reflection ' $A$ '). The thrust faults appear to terminate in the Windsor Group, where movement on the thrusts is transferred to backthrusts and/or transformed into disharmonic folding above a decollement within the Windsor Group evaporites.
\end{abstract}

Des profils gravimétriques et des données de réflexion sismique de l'industrie pétrolière ont été utilisés aux fins de l'interprétation de structures géologiques côtières et marines du sous-bassin du Carbonifère d'AntigonishMabou. Quatre horizons sismiques ont été cartographiés et on a levé les courbes de niveau de l'horizon le plus profond (réflexion " $\mathrm{A}$ ", près de la base du Groupe de Windsor) afin de réaliser une carte de la structure temporelle du sous-bassin. Le sous-bassin d'Antigonish-Mabou est structuralement complexe et il s'approfondit à 2,8 $s$ dans les deux sens $(5600 \mathrm{~m}$ ) dans le centre-nord de la baie de St. Georges. Il est substantiellement plus mince dans les secteurs côtiers des régions d'Antigonish (jusqu'à $1,0 s-2000 \mathrm{~m}$ ) et de Mabou (jusqu'à $1,6 s-3200 \mathrm{~m}$ ).

Les données géophysiques ont révélé des structures plus complexes à des profondeurs importantes que ce qu'avaient précédemment montré la cartographie superficielle, les trous de sonde ou les données des profils sismiques marins de pénétration peu profonde. À l'intérieur du sous-bassin, on a cartographié des poussées subhorizontales et des décrochements à fort pendage, des structures salifères et des blocs du socle soulevés. Quelques failles présentent d'importants rejets verticaux (jusqu'à $3200 \mathrm{~m}$ ) et de gros blocs séparés du socle soulevés de points plus profonds du bassin. Le mouvement des failles est postérieur à l'âge du Groupe de Windsor. On possède de nouvelles preuves de la formation de failles grâce aux données sismiques sur le sud de la baie de St. Georges, aux profils sismiques côtiers du secteur de la rivière Mull, ainsi qu'aux profils gravimétriques du secteur proche d'Antigonish. Seule une de ces failles chevauchantes a été cartographiée en surface par les géologues précédemment actifs dans la région.

Les failles chevauchantes placent le Groupe de Windsor et les roches plus anciennes au-dessus des réflexions basales du Groupe de Windsor (réflexion "A»). Les failles chevauchantes semblent s'évanouir dans le Groupe de Windsor, où le mouvement exercé sur les poussées est transféré à des rétrocharriages ou transformé en un pli dysharmonique au-dessus d'un décollement à l'intérieur d'évaporites du Groupe de Windsor.

[Traduit par la rédaction]

* Geological Survey of Canada Contribution No. 29495.

* Present Address: Durling Geophysics, 36 Beaufort Drive, Dartmouth, Nova Scotia B2W 5V4, Canada.

Atlantic Geology

31, 183-196 (1995)

0843-5561/95/030183-14\$3.10/0 


\section{INTRODUCTION}

Thrust faults affecting Carboniferous rocks have been interpreted at various localities throughout Atlantic Canada. For example, geological evidence for low-angle thrust faults and associated folds has been presented from southeastern New Brunswick (Gussow, 1953; Nance, 1987), the Cobequid Highlands (Waldron et al., 1989; Durling, 1996) and Cape Breton Island (Weeks, 1954; Currie, 1977). Regional seismic reflection studies have shown that thrust faults may be present offshore beneath the Gulf of St. Lawrence (Durling and Marillier, 1993a).

Few thrust faults have been reported in the AntigonishMabou Subbasin (Fig. 1; Norman, 1935; Boehner and Giles, 1993). Faults in the Carboniferous rocks of the subbasin are rarely exposed in outcrop (Kelly, 1967), however, and their attitude is commonly deduced from other information (i.e., boreholes). For example, high angle reverse faults were interpreted in southwestern Cape Breton Island where overturned folds of Carboniferous rocks were juxtaposed against pre-Carboniferous basement rocks (Kelly, 1967). However, the dip of such faults is not known, and subsurface information is required to determine the attitude of the fault. Recently, a thrust fault was interpreted in the AntigonishMabou Subbasin, with subsurface information provided by a deep borehole (Giles et al., in press). The thrust fault places the Craignish Formation of the Horton Group (Fig. 2) on younger rocks of the Strathlorne and Ainslie formations, in the Mull River area (Fig. 1). Previously, this structure was interpreted as an over-turned fold (Norman, 1935).

Geophysical data can provide the additional constraints needed to give three dimensional interpretations of geological structures. In this paper, we present: (1) a time-structure map showing the structural configuration of the Antigonish-

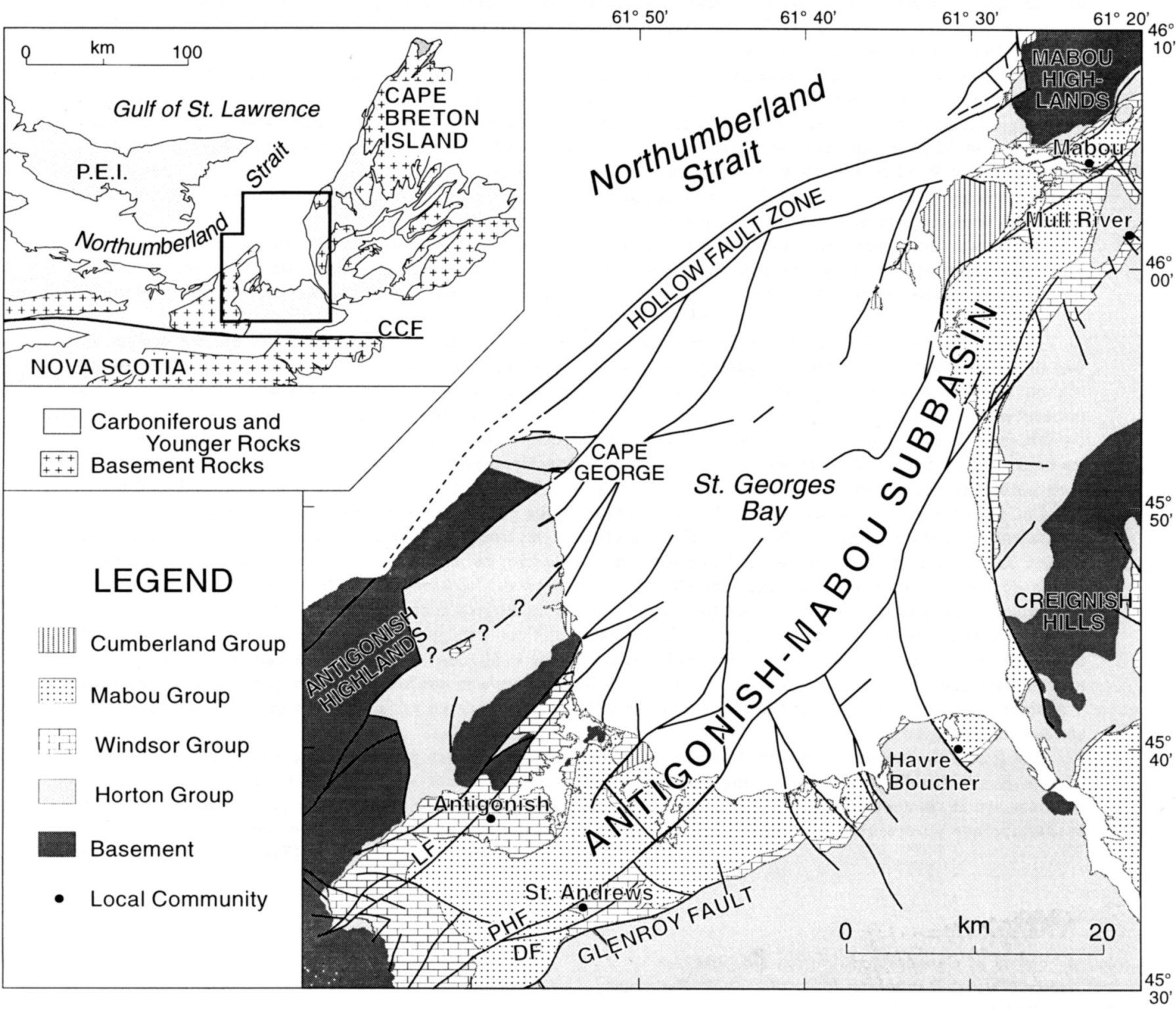

Fig. 1. Simplified geology map of the Antigonish-Mabou Subbasin (after Durling et al., 1995). Abbreviations: DF = Dunmore Fault; LF $=$ Lanark Fault; PHF $=$ Pomquet Harbour Fault. Inset abbreviations: $C C F=$ Cobequid-Checabucto Fault; P.E.I. $=$ Prince Edward Island. 


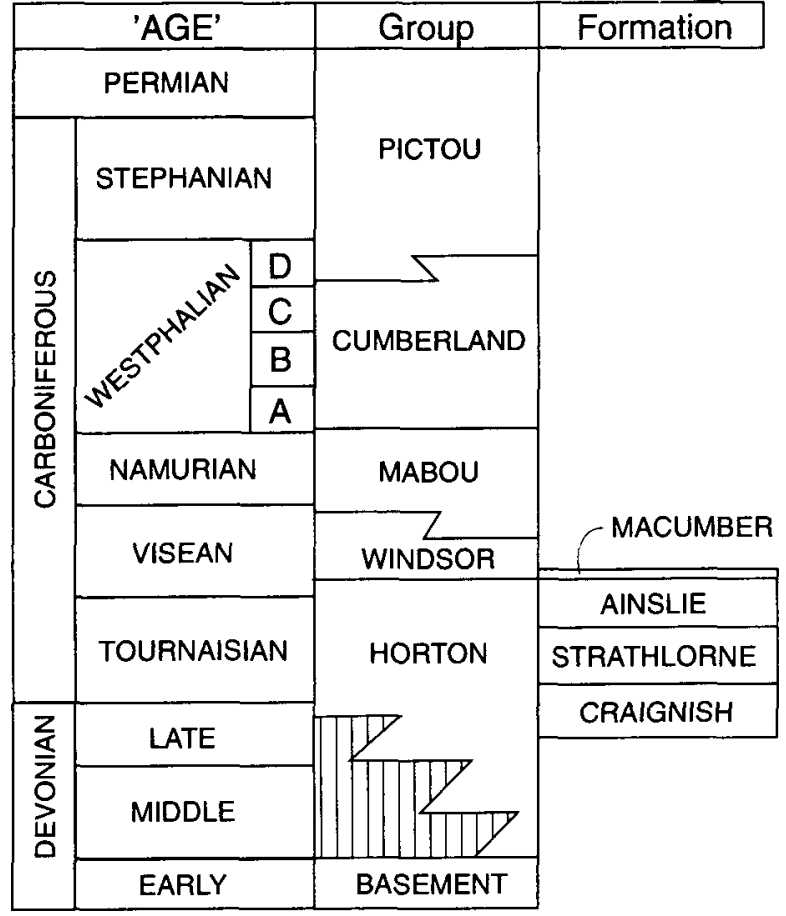

Fig. 2. Simplified stratigraphy showing the group names applied to rocks in the Carboniferous basins of eastern Canada (adapted from Ryan et al., 1991; Kelly, 1967). Formation names are given only for units discussed in the text and may not be regionally applicable. Vertical line pattern indicates period of erosion or non-deposition.

Mabou Subbasin, and (2) geological and geophysical evidence supporting thrust fault interpretations of several structures in the study area. Some of the structures studied were previously published, whereas others are presented for the first time (i.e., from beneath St. Georges Bay). This paper documents evidence for thrust faults and presents a brief discussion of the kinematics of one thrust structure. Determinations of the timing of thrust fault activity, its relationship to regional tectonics, and its effects on Carboniferous sedimentation, if any, await complete analysis of the basin fill.

This paper is the product of a joint study involving the Geological Survey of Canada (GSC) and the Nova Scotia Department of Natural Resources (NSDNR), under the CanadaNova Scotia Mineral Development Agreement (1992-1995).

\section{Regional geology}

The Antigonish-Mabou Subbasin is situated in northeastern Nova Scotia, on the southern coast of the Gulf of St. Lawrence (Fig. 1: inset). It is centred on St. Georges Bay and extends northeasterly into western Cape Breton Island and southwesterly into eastern mainland Nova Scotia. It is located north of the Cobequid-Chedabucto Fault.

Beneath and adjacent to the Antigonish-Mabou Subbasin, "basement" consists of Lower Devonian and older rocks which outcrop in the Antigonish Highlands, the Creignish Hills and the Mabou Highlands (Fig. 1). Strata of mostly Late Devonian and Carboniferous age outcrop in the Antigonish-
Mabou Subbasin (Fig. 2). These rocks consist mainly of coarseto fine-grained, red to grey continental clastics, with the exception of the Windsor Group, which consists mainly of a marine limestone-evaporite succession with local, interbedded redbed clastics (Boehner and Giles, 1993; Benson, 1970). In places, the evaporites have flowed and form large diapiric structures (Boehner, 1986).

Strata within the Antigonish-Mabou Subbasin are folded into northeast trending, open synclines (Durling et al., 1995). Northeast striking faults, intruded by Windsor Group evaporites, separate the synclines (Fig. 1). Locally, there are north to northwest trending faults.

The northeast trending Hollow Fault Zone (Durling et al., 1995) is one of the major geological features in the area. It separates the Carboniferous rocks in St. Georges Bay from those in the Gulf of St. Lawrence to the north, and is mapped offshore as a 1500 to $2500 \mathrm{~m}$ wide deformation zone (Fig. 1). The Hollow Fault is interpreted as a late Carboniferous strike-slip fault (Yeo and Ruxiang, 1987).

\section{THE SEISMIC DATABASE}

The seismic reflection data used in this study were collected by the petroleum industry between 1974 and 1983 (Fig. 3). The seismic database comprises about 750 linekilometres of data. The quality of the seismic reflection data varies from fair to poor in the Antigonish-Mabou Subbasin. The poorest quality data are found near salt structures, on the southern margin of St. Georges Bay, and onshore where, locally, the basin is shallow and is affected by faulting or salt tectonism.

The Nova Scotia Department of Natural Resources reprocessed $240 \mathrm{~km}$ of the 1982 Chevron seismic reflection data collected in St. Georges Bay (Fig. 3). Consequently, digital seismic profiles were available during this study. The digital data were interpreted on a seismic workstation at GSC Atlantic. The remaining seismic profiles in the study area were available only as paper sections. Seismic horizons interpreted on the paper sections were digitized for integrated interpretation with the digital data.

\section{TIIE SEISMIC HORIZONS}

Four seismic horizons were mapped in the AntigonishMabou Subbasin (Fig. 4). They were selected chiefly on the basis of reflection strength and continuity. The deepest horizons, reflections ' $A$ ' and ' $B$ ', correspond to the bottom and top, respectively, of a band of continuous to discontinuous, high amplitude reflections. The band tends to thicken adjacent to the interpreted salt structures and to thin (almost to zero thickness) between salt structures on some survey lines. Reflection ' $A$ ' appears to form the base of the salt structures, where such a base can be mapped. It is interpreted as a "near base of Windsor Group" seismic event. In most locations, this horizon appears to be the base of the mappable, coherent reflectors (acoustic basement), especially where the basin thins. Elsewhere, reflection ' $A$ ' is locally underlain by reflections which are interpreted as represent- 


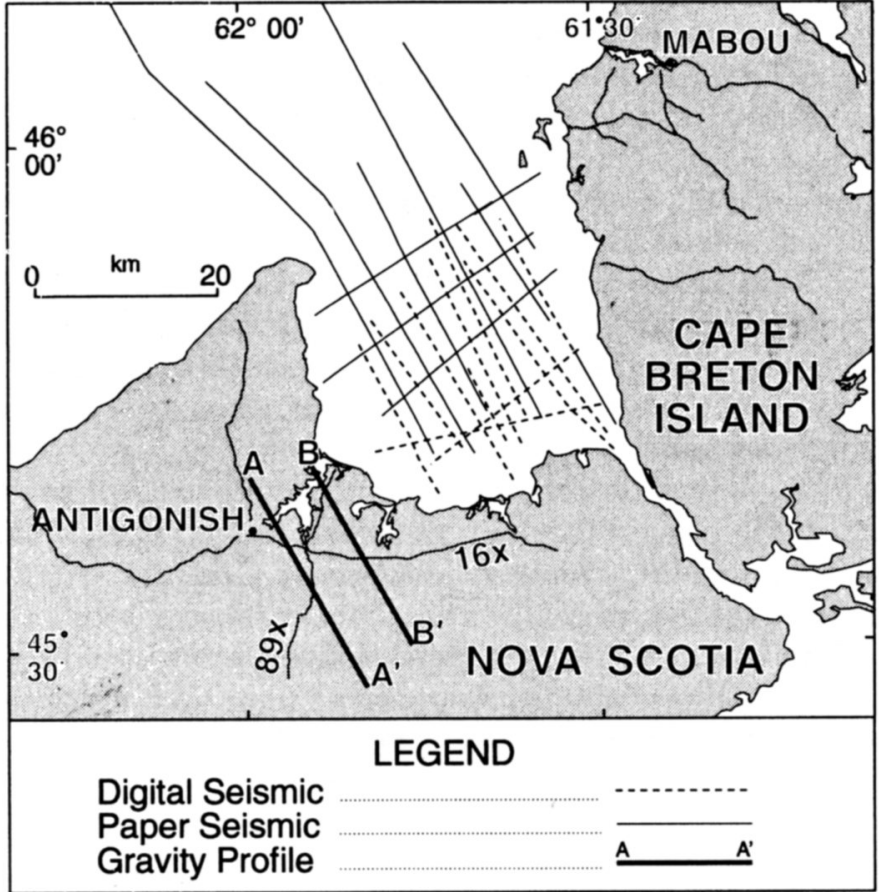

Fig. 3. Distribution of seismic reflection and gravity profiles used in this study.

ing stratified rocks, possibly of the Horton Group. Reflection ' $B$ ' is interpreted as the highest Windsor Group reflection in St. Georges Bay.

A second band of high amplitude reflections occurs approximately 1.0 to $1.5 \mathrm{~s}$ above reflection ' $\mathrm{B}$ '. The reflection which displays the highest amplitude and greatest continuity, commonly at the top of the band of high amplitude reflections, was chosen as reflection ' $\mathrm{C}$ ' (Fig. 4). Overlying reflection ' $\mathrm{C}$ ' is a sequence of low amplitude reflections, which is in turn overlain by a narrow band of high amplitude reflections. Reflection ' $D$ ' (Fig. 4) was selected as the highest amplitude and most continuous reflection from within this upper band of reflections. Reflection ' $D$ ' represents the shallowest mappable seismic event in St. Georges Bay. Reflections ' $C$ ' and ' $D$ ' probably correspond to Upper Carboniferous coal strata (Hacquebard et al., 1989).

Reflection ' $A$ ', which we regard as the top of 'acoustic basement', is the deepest regionally mappable reflection in the study area. Therefore, though we would prefer to present contours on a top of basement horizon to show basin depth, reflection ' $A$ ' is the best approximation of a basement event obtainable from the seismic data. Contours on reflections ' $B$ ', ' $C$ ' and ' $D$ ' describe the structure of the basin sediments, and will be presented elsewhere.

\section{TIME STRUCTURE MAP OF REFLECTION 'A'}

The time structure map of reflection ' $A$ ' (base of the Windsor Group reflection; Fig. 5) shows a complex structural configuration. The contours on this horizon form an elliptical pattern in the north central part of the AntigonishMabou Subbasin, where the basin is about $2.8 \mathrm{~s}$ deep (5600

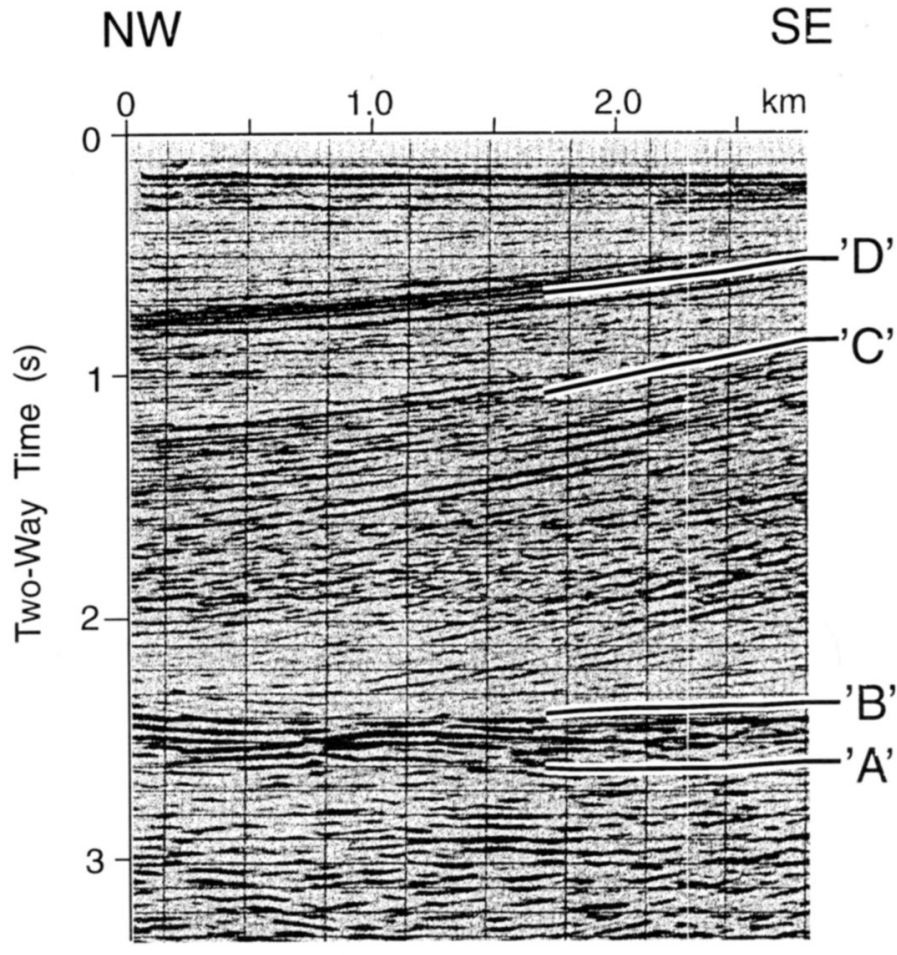

Fig. 4. Seismic reflection profile 82-61-11F from St. Georges Bay, showing the seismic horizons ( $A, B, C$, and D) mapped in this study. See Figure 5 for location.

$\mathrm{m}$ assuming a seismic velocity of $4000 \mathrm{~m} / \mathrm{s}$ ). The basin has elongate "tails" that extend northeasterly and southwesterly toward Mabou and Antigonish, respectively: it is up to $1.0 \mathrm{~s}(2000 \mathrm{~m})$ in the Antigonish area and up to $1.6 \mathrm{~s}(3200$ $\mathrm{m})$ in the Mabou area.

Several faults affect reflection ' $A$ '. These faults are of post Windsor Group age, but the age of their most recent movement is unknown. Thickness variations of seismic units and seismic unit boundary relationships suggest that most of the fault movement occurred during the Namurian to the Late Westphalian, with minor, later adjustments.

Some faults appear to separate large uplifted basement blocks from basinal areas. For example, the eastern margin of the Antigonish Highlands appears to be delineated by a northerly striking fault, which we interpret as the "Southside Harbour Fault" (SSHF in Fig. 5). Both onshore and offshore seismic data show a down-to-the-east, reverse offset of the Carboniferous rocks across this fault, with up to $600 \mathrm{~m}$ of inferred movement. On the east side of St. Georges Bay, Kelly (1967) mapped a north-south trending, high anglefault on the west side of the Creignish Hills. We named it the 'Judique Fault'.

The throw on some of the faults affecting reflection ' $A$ ' can be very large. The vertical offset of the base of the Windsor Group across the Judique Fault may be as much as $3200 \mathrm{~m}$ (assumed seismic velocity of $4000 \mathrm{~m} / \mathrm{s}$ ). The throw on the Hollow Fault Zone varies along its strike. Southwest of Cape George, the throw on the Hollow Fault Zone (Durling et al., 1995) is down to the north, whereas at the entrance to St. Georges Bay the throw is down to the south. Maximum ver- 


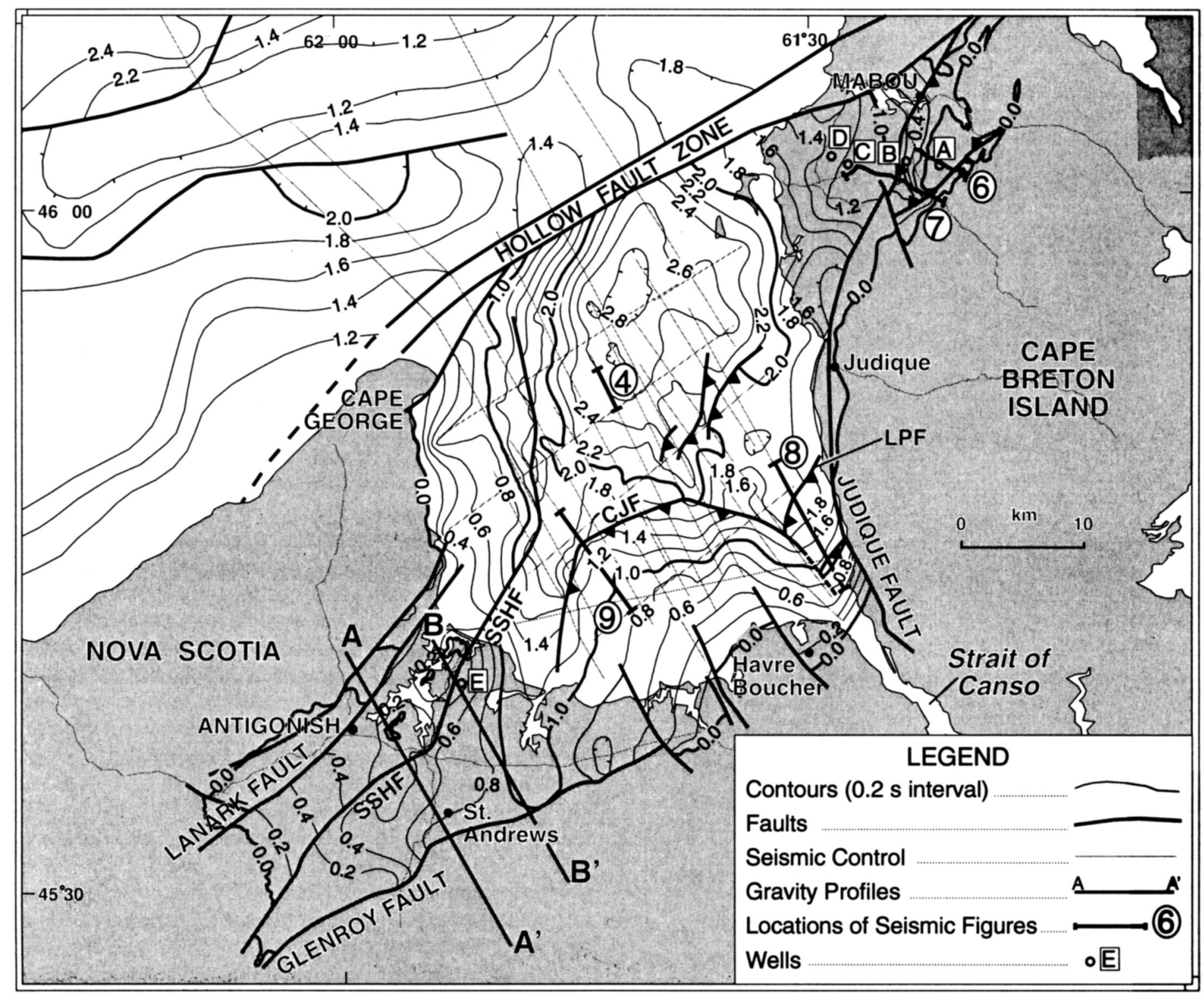

Fig. 5. Two-way time structure contour map of reflection ' $A$ '. Well labels: $A=$ Mull River No.1; $B=$ Mabou No.1; $C=M a c$ No.l; $D$ $=$ Port Hood No.1; E = Bras d'Or-Anschutz No.1. Abbreviations: SSHF = Southside Harbour Fault; CJF = Cape Jack Fault; LPF = Long Point Fault.

tical offset in St. Georges Bay is about $1600 \mathrm{~m}$, down to the south.

Time structure contours on the basal Windsor Group (equivalent of reflection ' $A$ ') from the Magdalen Basin (Durling and Marillier, 1993a) are shown northwest of the Hollow Fault Zone (Fig. 5). The difference in structural style on opposite sides of the Hollow Fault Zone is striking. The closer spacing of the contours in the Antigonish-Mabou Subbasin indicates that the basal Windsor Group reflections dip more steeply than in the Magdalen Basin. Also, the density and orientation of the faults are significantly different.

\section{Style of faulting in the Mull River area}

In the Mull River area (Fig. 1), the Windsor Group is exposed at the surface and outcrop patterns suggest the area is folded into open to close folds with associated minor faulting
(Norman, 1935; Giles et al., in press). Seismic reflection profiles in this area reveal the structural relationships in the subsurface. Figure 6 shows a seismic profile which passes through the Mull River No.1 well (well A in Fig. 5). Depths in the well were converted to time using the sonic log. The well was drilled through a structural repetition of the Horton Group (Fig. 2), where the Strathlorne Formation occurs beneath, and in faulted contact with, the Craignish Formation. At the surface, near the southeast end of the profile, vertical to overturned rocks of the Horton and Windsor groups were mapped (Norman, 1935; Giles et al., in press). We have interpreted a southeast directed thrust fault extending from the overturned strata at the surface through the fault in the Mull River No.1 well. This seismic interpretation is consistent with a recent interpretation of outcrop data and the Mull River No.1 well by Giles et al. (in press).

The seismic profile in Figure 7 is located about $3 \mathrm{~km}$ 


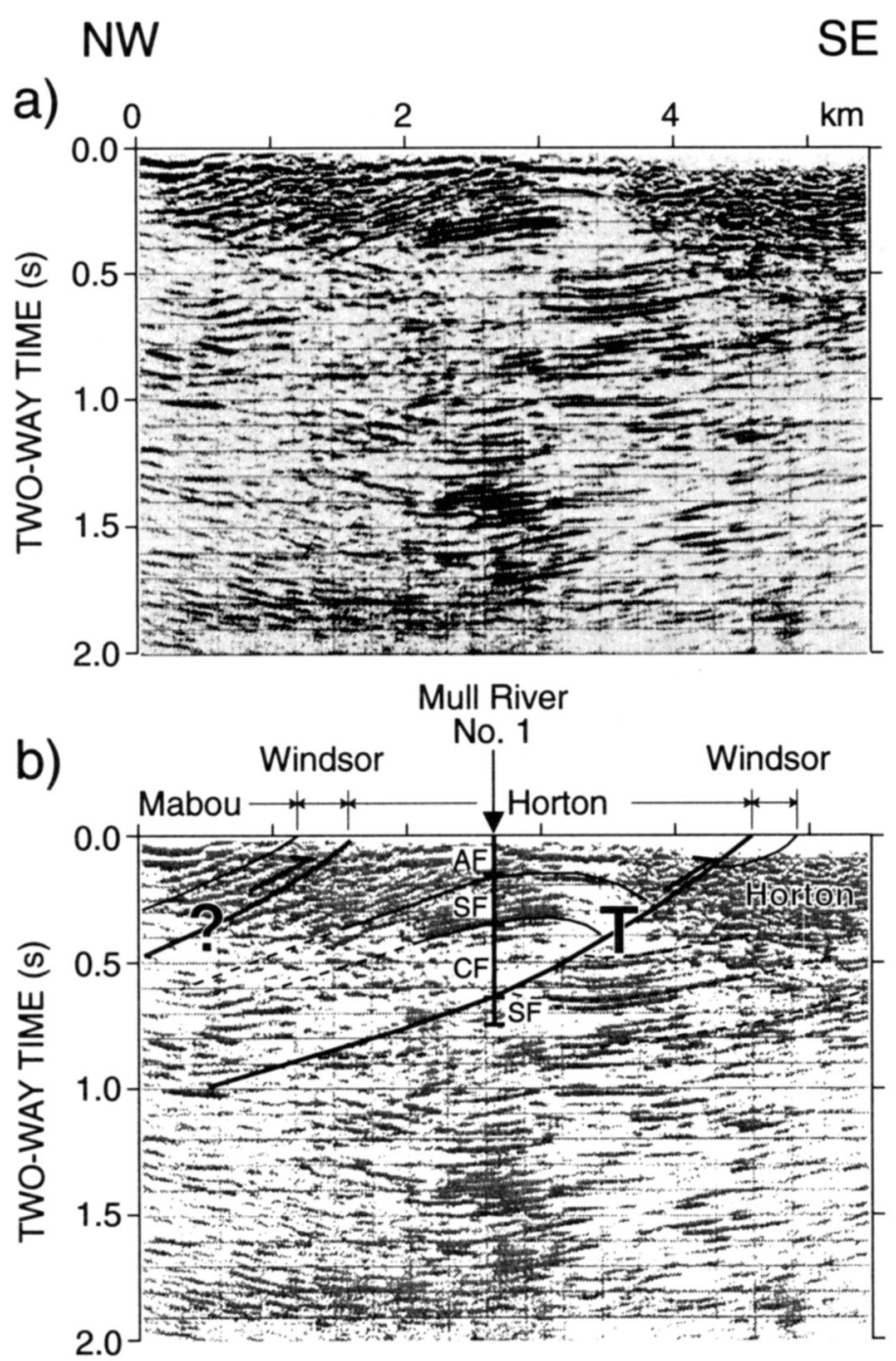

Fig. 6. Seismic reflection profile 37 from the Mull River area, Cape Breton Island: (a) uninterpreted profile and (b) interpreted profile. The letter ' $T$ ' indicates the location of probable thrust fault; 'CF', 'SF' and ' $A F$ ' denote the position of the Craignish, Strathlorne and Ainslie formations (respectively) of the Horton Group in the Mull River No.1 well. See Figure 5 for location.

southwest of the Mull River No.1 well. The profile shows a general lack of strong reflections, with the exception of discrete reflection packages in the central area of the figure. The lack of reflections may be an indication of steeply dipping strata, faulting or folding. Two distinct dip directions are indicated: a northwesterly apparent dip above $0.8 \mathrm{~s}$ twoway time (TWT), and a horizontal to southeasterly apparent dip below.

Identification of seismic reflections in Figure 7 was facilitated by correlation with the Mabou No.1 and Mac No.1 wells (wells B and C, respectively, Fig. 5), and by correlation with surface mapping (Norman, 1935, Giles et al., in press). Both wells were projected onto the seismic profile, parallel to the strike of rocks mapped at the surface. Correlation of seismic reflections with stratigraphic units identified in the wells are approximate, since velocity data was not available for these wells. We used an average velocity model developed in the Gulf of St. Lawrence (Durling and Marillier, 1993b) to convert from depth to two-way time.

A horizontal reflection at $1.0 \mathrm{~s}$ TWT, between 0 and 5 $\mathrm{km}$ along the profile (Fig. $7 \mathrm{~b}$ ), is interpreted as reflection ' $A$ ', as indicated by seismic ties with the Port Hood No.1 well (well $\mathrm{D}$ in Fig. 5). Beyond $5 \mathrm{~km}$, this reflection appears to be truncated by southeast dipping reflections that extend to $1.3 \mathrm{~s}$ TWT. Weak, less distinct reflections may extend to $1.7 \mathrm{~s}$ TWT at the extreme southeast part of the line.

Surface mapping indicates that the Windsor Group outcrops between 5.7 and $8.7 \mathrm{~km}$ along the profile (Fig. 7b). Therefore, the northwest dipping reflections occurring within this interval are probably Windsor Group reflections. This is supported by the Mabou No.1 well, where Windsor Group rocks correlate with the northwest dipping reflections. The Horton Group in the bottom of the Mabou No.1 well projects up dip, using the seismic reflection data, to Windsor Group outcrop. This apparent problem may be due to: (1) errors in seismic velocity; (2) the horizontal distance the well is projected; or (3) the inability of the seismic to image complex structure. For example, in the upper part of the seismic profile there are no coherent reflections, with the exception of the northwest dipping reflections in the central part. Additional faults and folds may be present in the subsurface which cannot be imaged by the seismic method.

The seismic, well and outcrop data indicate that Windsor Group and Horton Group rocks overlie reflection ' $A$ ', the basal Windsor Group horizon indentified in the Port Hood No.1 well. We suggest that a thrust fault (' $M$ ' in Fig. 7b) separates the northwest dipping reflections from reflection 'A'.

The northwest-dipping Windsor Group reflection package is composed of high amplitude, arcuate reflections and lower amplitude, discontinuous reflections (Fig. 7b). The high amplitude, arcuate reflections are abruptly truncated where they become horizontal. We suggest these horizons have been cut-off by southeast vergent thrust faults (' $T$ ' in Fig. 7b). The low amplitude reflections may represent additional thrust faulting, folding and/or shearing. Horizon ' $S$ ' marks the change in reflection character from chaotic, northwest dipping reflections above to chaotic reflections below. It extends to the surface in an area of Windsor Group outcrop. Horizon ' $S$ ' may indicate the presence of a fault analogous to the fault imaged in Figure 6 . However, there is very weak seismic evidence for this event on this seismic section (Fig. 7), indicating significant deformation has occurred in this area.

\section{Style of faulting in St. Georges Bay}

In the southern part of St. Georges Bay, two faults were mapped that mark the northern boundary of a large uplifted area (Fig. 5). The fault of greatest extent has a horseshoe shape, and we named it the Cape Jack Fault (CJF, Fig. 5). The other fault occurs east of the Cape Jack Fault, which we named the Long Point Fault (LPF, Fig. 5). Many more faults exist, as indicated by highly deformed strata, trun- 


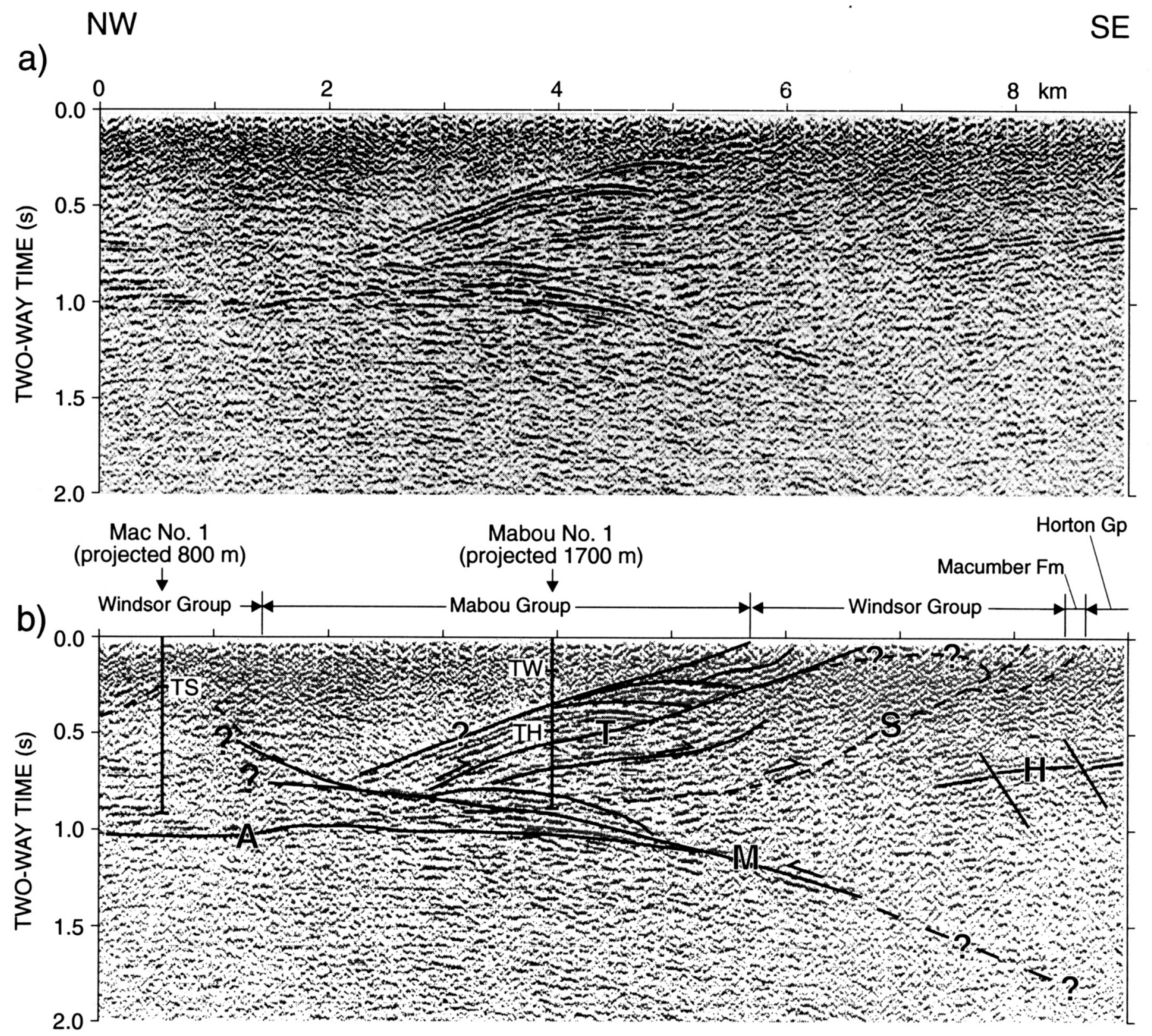

Fig. 7. Seismic reflection profile 62Y: (a) uninterpreted profile, (b) interpreted seismic profile. Abbreviations: $A=R e f l e c t o r ~ ' A ' ; ~ H$ = Horton Group reflections; $M=$ basal thrust fault; $S=$ base of a weakly stratified, Windsor/Horton Group seismic unit; $T=$ probable thrust faults; $\mathrm{TS}=$ top salt, $\mathrm{TW}=$ top Windsor Group, and $\mathrm{TH}=$ top Horton Group. See Figure 5 for location.

cated or discontinuous reflections, and areas of incoherent reflections imaged on the seismic profiles. These faults were considered to be minor and were omitted from Figure 5.

Figure 8 shows a reflection profile from southeastern St. Georges Bay across the Long Point Fault. The profile is of poor quality and shows few coherent reflections in its upper parts. Reflections which occur at two-way times of less than $1.0 \mathrm{~s}$, on the northwest end of the profile, are not labeled due to this line being isolated from borehole and outcrop data by faults and salt structures. Hence, the upper reflections cannot be identified. Reflection ' $A$ ' can be traced beneath the salt structures and was correlated with reflection ' $A$ ' on other seismic profiles. Reflection ' $B$ ' was identified on the basis of reflection character. Reflections ' $A$ ' and ' $B$ ' occur between 1.7 and $2.0 \mathrm{~s}$ on the northwest end of the profile (Fig. 8b). They dip southeasterly to a point about $5 \mathrm{~km}$ along the profile, where they appear to be truncated. Directly above this point, high amplitude, discontinuous reflections dip to the northwest and have a similar character to reflections ' $A$ ' and ' $B$ '. The reflections decrease in depth to about $0.8 \mathrm{~s}$ at the southeast end of the profile. The discontinuous character of the reflections suggests the presence of numerous faults. The rocks occurring beneath reflections ' $A$ ' and ' $B$ ' on the southeast end of the profile are likely to be Horton Group or basement rocks, rather than Windsor Group evaporites, since there is a positive gravity anomaly in this part of St. Georges Bay (see for example Durling et al., 1995, their fig. 7).

The geometry of reflections ' $A$ ' and ' $B$ ' (Fig. 8b) resembles reflection patterns observed in the Mull River area 


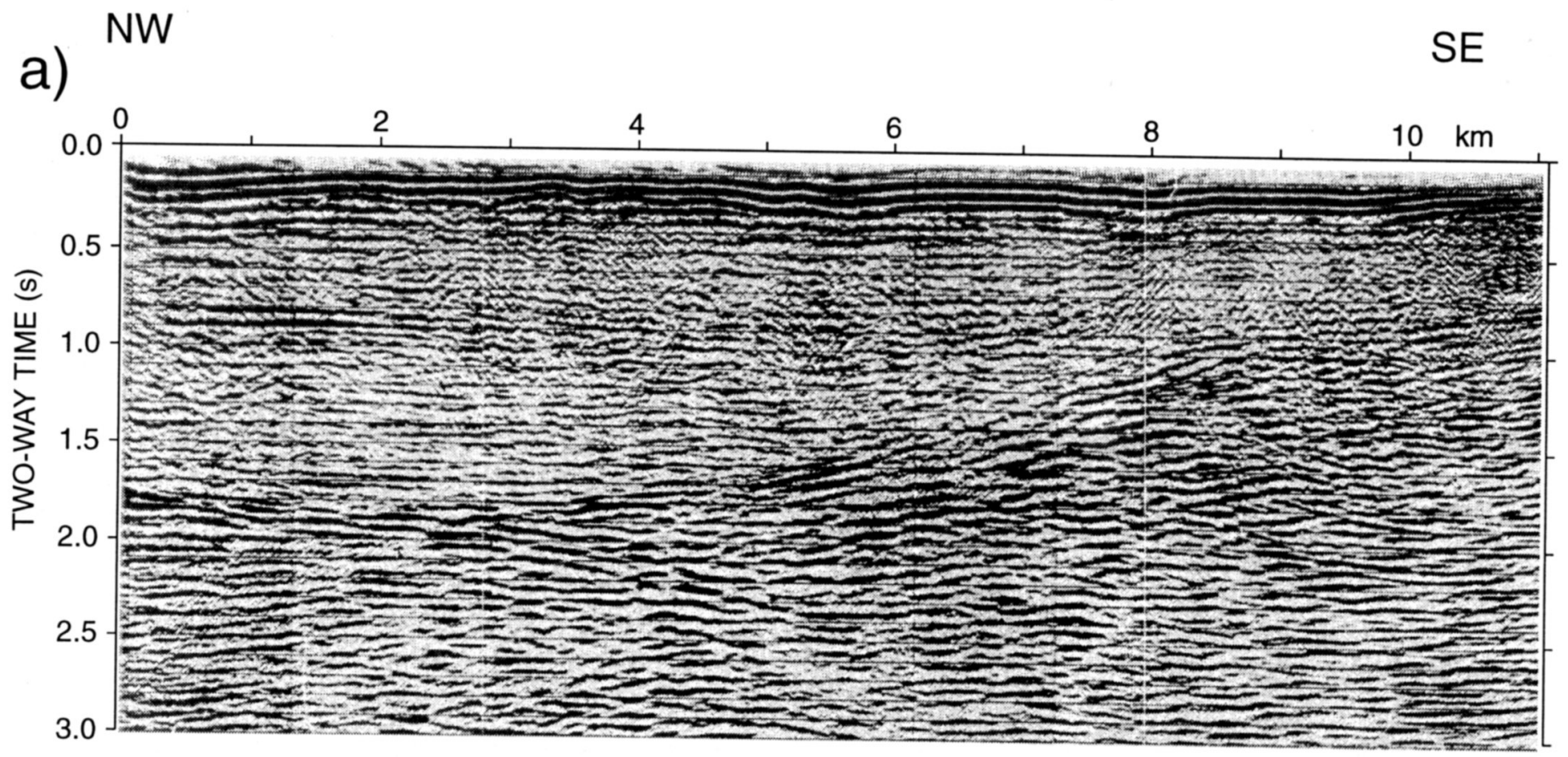

b)

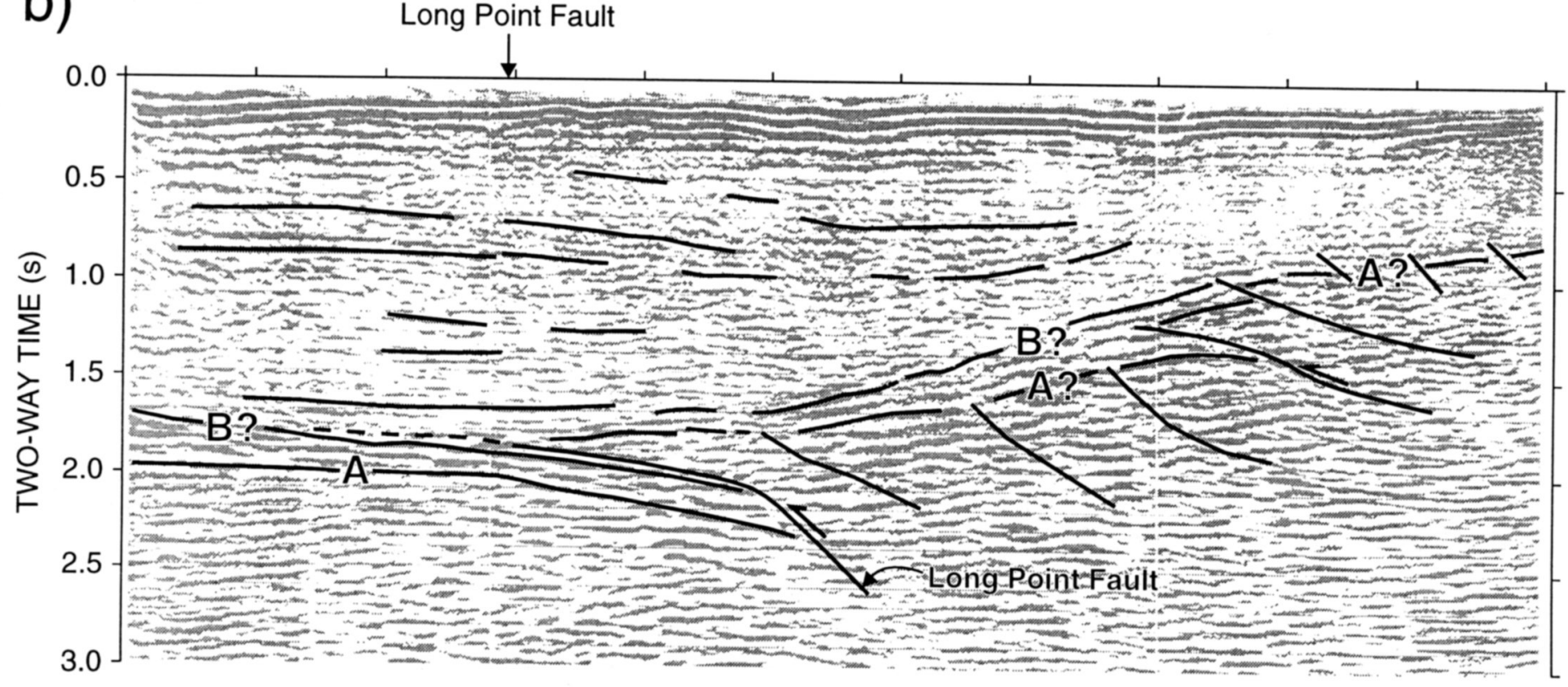

Fig. 8. Seismic reflection profile $82-49-11 \mathrm{~F}$ from St. Georges Bay: (a) uninterpreted, (b) interpreted. Abbreviations: $A=$ Reflector ' $A$ '; $B=$ Reflector ' $B$ '. See Figure 5 for location.

(Fig. 7b), suggesting the structures in both areas are formed by similar processes. Consequently, we are interpreting a thrust fault on the seismic section which places Windsor and Horton Group rocks in the hanging wall over Windsor Group rocks in the foot wall. The identification of reflections ' $A$ ' and ' $B$ ' in the hanging wall cannot be confirmed due to the lack of borehole and outcrop data. Gravity data (Durling et al., 1995) and Horton Group outcrop on the southern coast of St. Georges Bay (Fig. 1) suggest, however, that the Antigonish-Mabou Subbasin thins to the south, consistent with our interpretation.

Reflections occurring above reflection ' $B$ ' display significant thinning toward the southeast. There appears to be a gradual thinning of all strata, which may have been caused by onlap of sediments onto a basement uplift or rising salt mass (Jenyon, 1986). Lynch and Brisson (1994) suggested widespread extensional faulting in western Cape Breton Island. Extensional features such as roll-over anticlines and reflection truncations indicative of normal faulting are not apparent in Figure 8.

Figure 9 shows a seismic profile across the western part of the Cape Jack Fault. A salt structure (or a faulted, saltcored anticline of Durling et al., 1995), is imaged between 2 and $6 \mathrm{~km}$ along the profile. To the southeast and northwest of the salt structure are reflections labeled $R 1$ and $R 2$, respectively. Reflections $\mathrm{R} 1$ occur within a syncline that does 


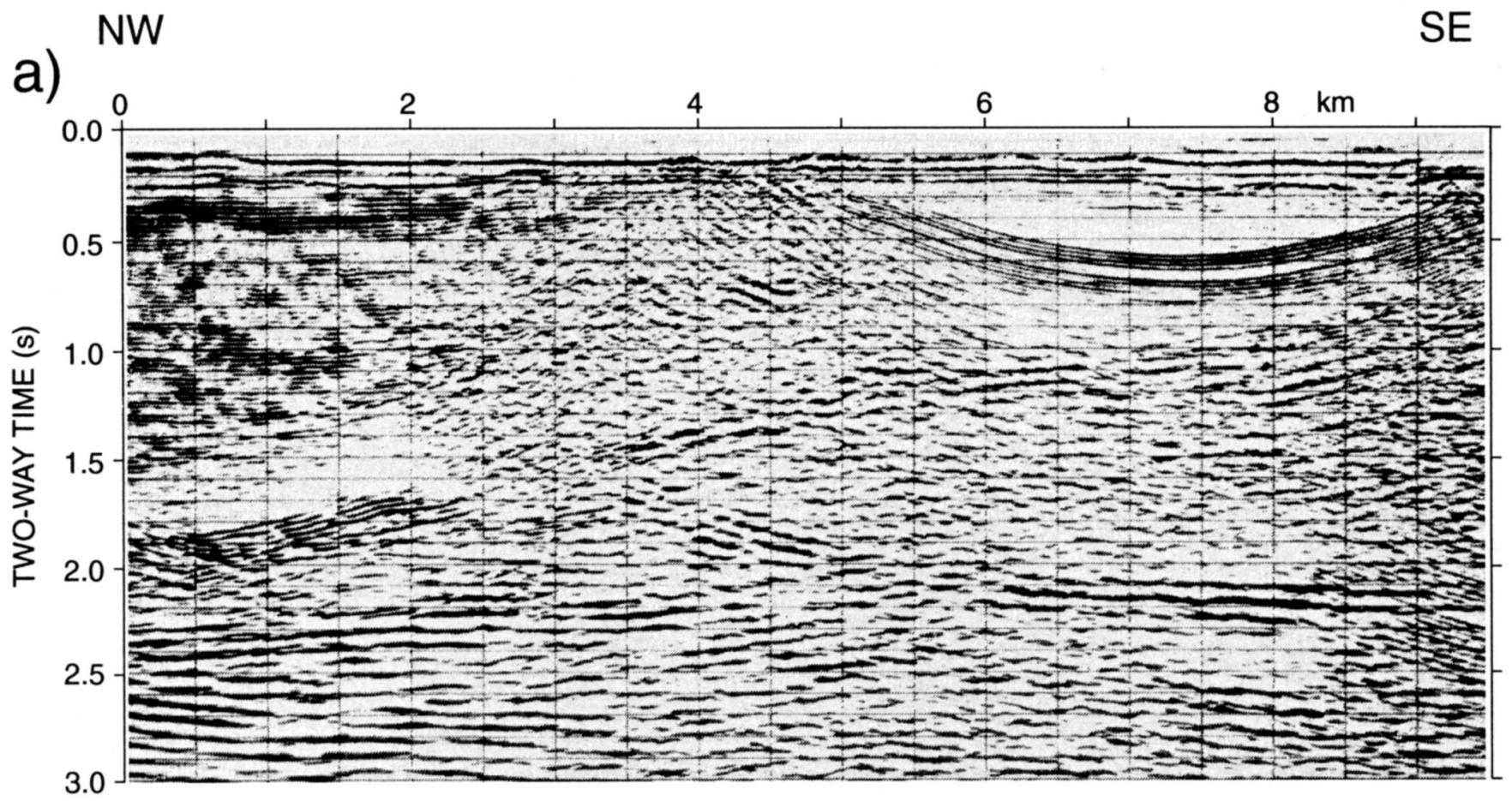

b)

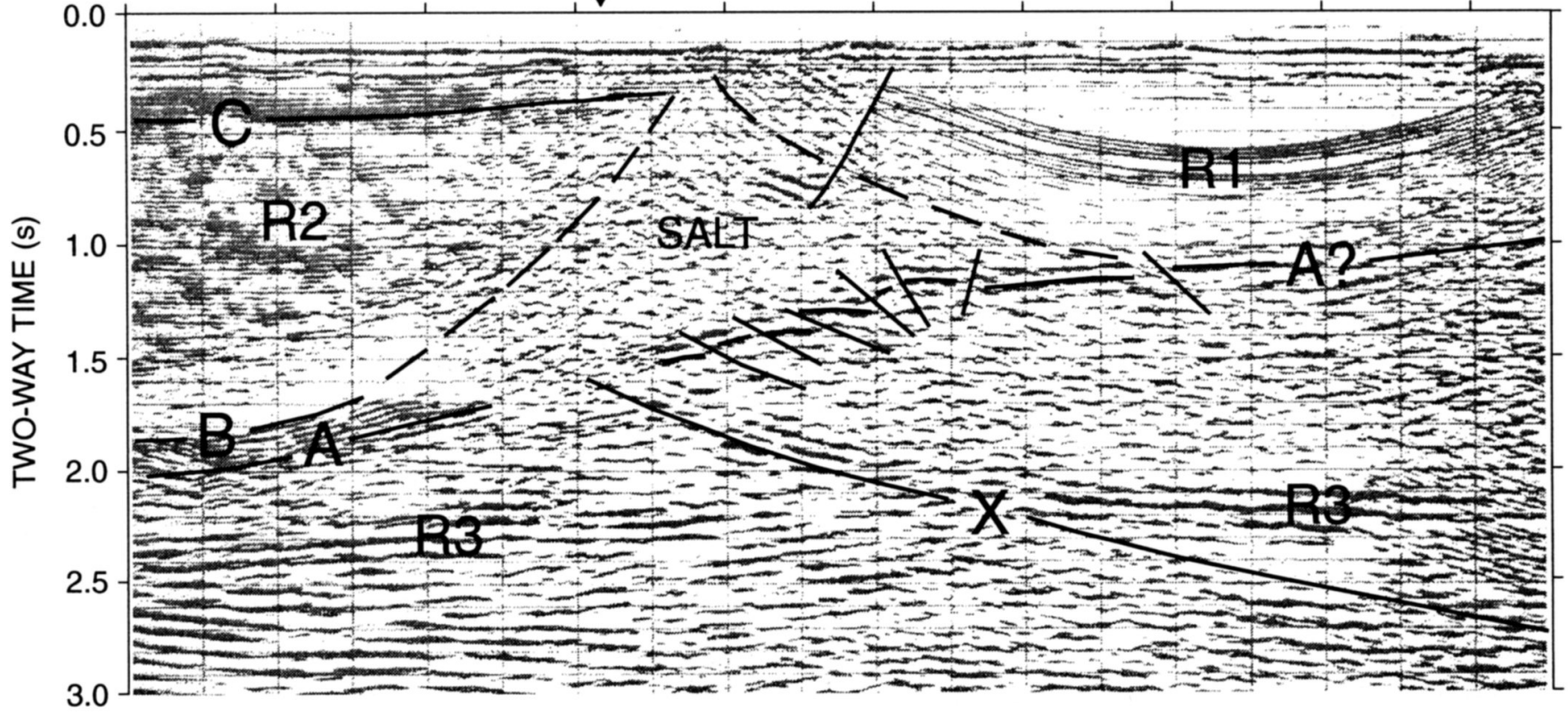

Fig. 9. Seismic reflection profile 82-71-11F from St. Georges Bay: (a) uninterpreted, (b) interpreted. Abbreviations: A = Reflector ' $A$ '; $B=$ Reflector 'B'; $C=$ Reflector ' $C$ '; $X=$ Cape Jack Fault, a probable thrust fault; R1, R2 and R3 are discussed in the text. See Figure 5 for location.

not extend onshore, and there are no boreholes located within this syncline. The reflection character of R1 most closely resembles that of reflection ' $D$ ' (Fig. 4). However, reflections Rl have not been correlated with any geological unit due to a lack of evidence. Reflections labeled R2 were directly correlated with reflections occurring between ' $B$ ' and ' $C$ ' on the seismic profile in Figure 4. Reflection ' $C$ ' is indicated at the top of the profile.

Reflection ' $A$ ' is imaged near $2.0 \mathrm{~s}$ at the northwest end of the profile (Fig. 9b). Between 2.5 and $3.5 \mathrm{~km}$ along the profile, reflection ' $A$ ' is absent. At $3.5 \mathrm{~km}$, a low amplitude, discontinuous reflection occurs at $1.5 \mathrm{~s}$ and decreases in depth to $1.0 \mathrm{~s}$ on the southeast end of the profile. This reflection is labeled ' $A$ ' since it appears to form the base of the salt structure. The discontinuous nature of the reflector is interpreted to be the result of a number of small faults (Howells and Roulston, 1991). The area where reflection ' $A$ ' is absent (between 2.5 and $3.5 \mathrm{~km}$ ) is interpreted as a 
large fault or faults, causing sufficient deformation to degrade the seismic response of reflection ' $A$ '. In the same area, low amplitude, southeast dipping reflections are interpreted as the fault plane (reflections ' $X$ ', Fig. 9b). Subhorizontal reflections occurring at about $2.3 \mathrm{~s}$ (labelled ' $R 3$ ') appear to be offset vertically across fault ' $X$ ' by about $0.1 \mathrm{~s}(400 \mathrm{~m})$. We propose that fault ' $X$ ' represents a low angle thrust fault, where rocks in the hanging wall have been uplifted and thrust northwestward into St. Georges Bay.

\section{INTERPRETATION OF GRAVITY PROFILES}

The onshore, seismic reflection survey coverage is sparse between Antigonish and the southwest coast of St. Georges Bay (Fig. 3). An improved geological interpretation was produced in this part of the subbasin by plotting two gravity profiles approximately perpendicular to the subbasin trend. These were used to help constrain the contours on reflection ' $A$ ' away from the seismic data, and to investigate the nature of the Glenroy Fault (Fig. 1).

The gravity data, in the Antigonish and adjacent areas, were measured by the Nova Scotia Research Foundation Corporation (1954, 1955 and 1969-1970) and Seismograph Services Corporation (1952). A small number of gravity stations, measured by the Geological Survey of Canada, were used to provide control for the regional gradient over the basement rocks of the Antigonish Highlands to the northwest. All the gravity data were reprocessed using the 1971 GSC Gravity Control Network, the 1967 International Gravity Formula and a Bouguer Density of $2.67 \mathrm{~g} / \mathrm{cm}^{3}$. The reprocessing is described in Howells and Clarke (1995).

The present gravity study used an interactive, PC based, 2.5 D modelling program MAGRAV2 (Broome, 1986). Two northwest-southeast gravity profiles were modelled (AA' and BB'; Figs. 3, 5). Seismic reflection, borehole and outcrop data were projected onto the gravity models to constrain the initial models. A "regional" gravity gradient was first subtracted from the observed gravity of each profile to give a residual gravity anomaly (Fig. 10). Assumed densities of $2.50,2.40$ and $2.15 \mathrm{~g} / \mathrm{cm}^{3}$ (Howells, 1973a, b) were used for the Windsor Group sediments, gypsum and salt, respectively. A density of $2.65 \mathrm{~g} / \mathrm{cm}^{3}$ was assumed for the Horton Group sediments and basement rocks. The half strike lengths of the Windsor Group sediments, salt and gypsum bodies in the models were assumed to be $17,9.5$ and $5 \mathrm{~km}$, respectively.

Blanchard (1956) quantitatively modelled, in two dimensions, a gravity profile in the St. Andrews area (Fig. 5), for which the profile location was not given. Blanchard's model is flat bottomed at a depth of $1660 \mathrm{~m}$, and shows a $2700 \mathrm{~m}$ wide, "pear shaped", salt body located about 2300 $m$ north of the Horton/Windsor Group faulted contact. This contact was interpreted by Blanchard as a steeply dipping $\left(80^{\circ}\right)$ reverse fault.

Gravity profile AA' intersects seismic line 89x (Fig. 3). The model (Fig. 10) shows a large, low density salt mass occupying the deepest part of the subbasin (about $1320 \mathrm{~m}$ in depth). The depth to the bottom of the basin is placed at reflection ' $A$ ' at the intersection with line $89 x$, which is at about $1200 \mathrm{~m}$, assuming a seismic velocity of $4000 \mathrm{~m} / \mathrm{s}$. The top of the salt structure is at $270 \mathrm{~m}$, somewhat shallower than the $360 \mathrm{~m}$ given by Boehner (1986) on the basis of boreholes located about $4.5 \mathrm{~km}$ east of the profile. However, the depth to the top of the salt would be greater if the depth to the bottom of the basin was deeper than initially assumed. Seismic line $89 x$ is a poor quality profile. Deeper reflections might be equivalent to reflection ' $A$ ', although they would be less consistent with other seismic profiles in the area. In addition, the assumption of a higher seismic velocity would result in a greater depth to reflection ' $A$ '.

The surface location of the Glenroy Fault occurs at 16 $\mathrm{km}$ on profile $\mathrm{AA}^{\prime}$. It is modelled as a thrust because the residual anomaly gradient requires lower density rocks in the subsurface, southeast of the surface location of the fault. An additional fault (?thrust) may occur within the subbasin on the south flank of the main salt structure, which may correlate with the Dunmore Fault mapped at the surface by Boehner and Giles (1993).

The northern margin of the subbasin on profile $\mathrm{AA}^{\prime}$ is defined by the Lanark Fault (see Fig. 1 for location). A thin wedge of Windsor Group gypsum is interpreted to explain the gravity anomaly between 3.5 and $9 \mathrm{~km}$ on the profile, and matches gypsum outcrop mapped by Boehner and Giles (1993). The Southside Harbour Fault is interpreted to form the northern edge of the deeper part of the sedimentary basin about $9 \mathrm{~km}$ along the profile. This interpretation is supported by outcrop, borehole, and seismic data which show that basement occurs at very shallow depths northwest of the fault, whereas seismic line 16x suggests basement occurs at a depth of at least $600 \mathrm{~m}$ southeast of the fault.

Profile BB' is parallel to and about $6 \mathrm{~km}$ east of profile $\mathrm{AA}^{\prime}$ (Fig. 3). This profile intersects seismic line 16x, which trends approximately east-west. The model (Fig. 10) shows that low density salt is continuous across most of this part of the subbasin. However, in contrast to the interpretation of $\mathrm{AA}^{\prime}$ and, in agreement with Blanchard's (1956) interpretation, salt is absent between the southern flank of the main salt mass and the Glenroy Fault, a horizontal distance of about $1.7 \mathrm{~km}$. The maximum subbasin depth is about 1660 $\mathrm{m}$, determined from seismic profile $16 \mathrm{x}$. The shallowest part of the main salt body, in the southern half of the subbasin, is at $670 \mathrm{~m}$. This is deeper than the published depths (Boehner, 1986) from boreholes located about $1.5 \mathrm{~km}$ west of profile $\mathrm{BB}^{\prime}$. This is to be expected as profile BB' is east of the centre of the gravity low.

The Glenroy Fault is again interpreted as a thrust, but the dip of the fault is much steeper than for profile AA'. Seismic line 89x (Figs. 3, 5) across the fault shows incohernet reflections and cannot be interpreted with confidence. The Southside Harbour Fault is interpreted at about $3.5 \mathrm{~km}$ along the profile. Granite outcrop occurs to the northwest of this fault (Boehner and Giles, 1993). To the southeast of the SSHF, the Bras d'Or-Anschutz No. 1 well (well E, Fig. 5) recorded a depth to the base of the Windsor Group of about $585 \mathrm{~m}$ (Boehner, 1986). This well was used as control for both the top and bottom of the salt mass in the profile BB' model. 


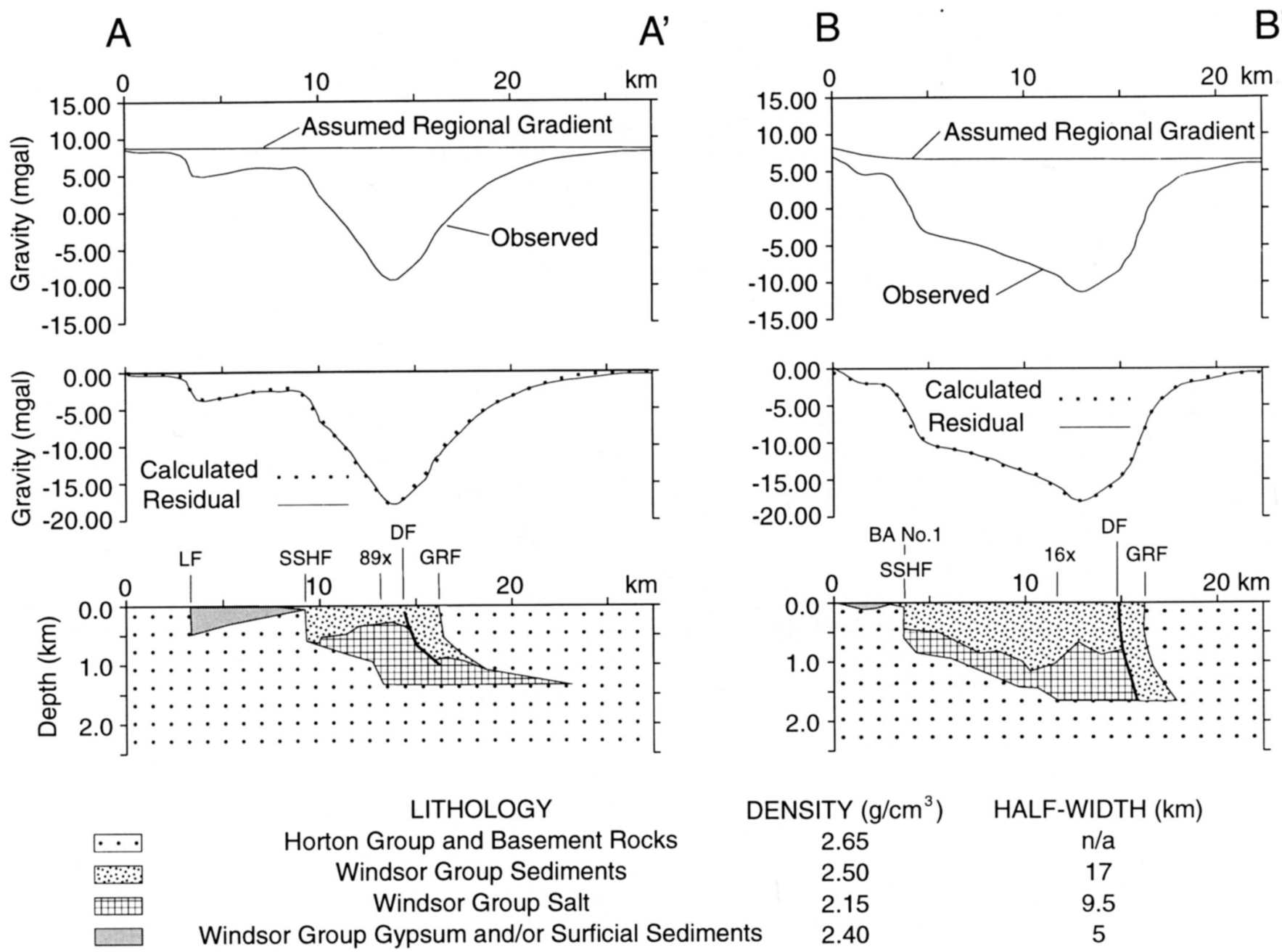

Fig. 10. Gravity models from the Antigonish area. Abbreviations: LF = Lanark Fault; GRF = Glenroy Fault; DF = Dunmore Fault; SSHF $=$ Southside Harbour Fault. See Figures 3 and 5 for location.

For both profiles AA' and BB', a small body of Windsor Group gypsum has been incorporated at the northwestern end of the model. Gypsum and anhydrite, 100 to $200 \mathrm{~m}$ in thickness, have been reported by Boehner and Giles (1993) in the vicinity of Antigonish Harbour. The maximum interpreted gypsum thicknesses are 470 and $110 \mathrm{~m}$ respectively for profiles $\mathrm{AA}^{\prime}$ and $\mathrm{BB}^{\prime}$. Lower density (e.g., $2.1 \mathrm{~g} / \mathrm{cm}^{3}$ ) surficial sediment (e.g., river alluvium, glacial till) may also be present in a northeasterly trending, overdeepened glacial channel, beneath Antigonish Harbour. This could also contribute to the small negative anomaly attributed to the gypsum layer in the models.

\section{Discussion}

Seismic reflection profiles in several parts of the AntigonishMabou Subbasin show reflection patterns indicating deformation. The profiles display reflections with intersecting apparent dip directions and reflections that terminate against other reflections. The seismic data alone are not sufficient to establish a unique geological interpretation; however, when interpreted with borehole and outcrop data, they suggest that some overthrusting has occurred. The timing of thrusting has not been addressed, for this is beyond the scope of this paper. Some aspects of the kinematics of thrusting need to be considered to more fully assess whether thrusting can reasonably explain structures observed in the AntigonishMabou Subbasin.

Previous to this study few thrust faults were interpreted in the Antigonish-Mabou Subbasin (Norman, 1935; Kelly, 1967; Boehner and Giles, 1993; Lynch and Brisson, 1994; Giles et al., in press). This may be due to poor exposure of thrusts rather than an absence of thrust faults. In the northern Canadian Rocky Mountains large mappable thrust faults are rare (Thompson, 1981). They typically occur as subsurface ('blind') thrusts which terminate at depth in decollement zones of incompetent shales, where motion on the thrusts is dispersed into the overlying strata, producing disharmonic folds (Thompson, 1981). Therefore, thrusts occur mainly in the subsurface, and folding is the primary indicator of their presence. In the Antigonish-Mabou Subbasin, rocks at the surface are folded into northeast trending open synclines and faulted, salt cored anticlines (Durling et al., 1995). These fold patterns are not represented in the deeper rocks (i.e., reflection ' $A$ '; Fig. 5), indicative of disharmonic folding. A disharmonic fold from St. Georges Bay is illustrated in Fig- 
ure 9, where the syncline at the southeast end of the profile overlies a faulted and slightly antiformal reflection ' $A$ '. A decollement surface may be interpreted immediately above reflection ' $A$ ' (basal Windsor Group). By analogy with the northern Canadian Rocky Mountains, the incompetent evaporites of the Windsor Group may be considered a zone of possible decollement, and the faulted salt anticlines (Durling et al., 1995) may be considered disharmonic folds.

Figure 11 is a block diagram showing a possible interpretation of the Mull River area, based on the seismic profiles in Figures 6 and 7, and the surface geology (Norman, 1935). Two thrust fault dip directions, with opposing dips, were interpreted. The basal thrust fault ("btf" in Fig. 11), which displaces the basement rocks, drives the system. Motion on the fault is transferred upward to the Windsor Group evaporites where the basal thrust fault becomes a bedding parallel fault within the Windsor Group. It is interpreted as a 'blind' thrust (Thompson, 1981) since it is not known to outcrop within the study area, and projection of the fault to the surface cannot be demonstrated with the seismic data (fault ' $M$ ' in Fig. 7). Movement on the basal thrust may terminate within the evaporites, where differential movement between the hanging wall and the foot wall may produce shortening in the Carboniferous cover in the form of folding (i.e., development of salt structures or faulted anticlines; Durling et al., 1995). This is suggested by the large thickness of salt encountered in the Mac No.1 well (Fig. 7). In addition, as depicted in Figure 11, back-thrusts may develop (Fig. 6), transferring some of the fault motion to the surface. The net result is that during compression, the rocks in the hanging wall of the basal thrust moved northwesterly and acted in a similar manner to a plow, by wedging beneath and folding upward part of the Windsor Group and its overlying strata. Only a portion of the Windsor Group was tectonically removed: Windsor Group evaporites occurring in the foot wall of the basal thrust fault may have acted as a lubricant to facilitate fault motion (Davis and Engelder, 1985). Windsor Group evaporites have been mapped within the study area (i.e., Giles et al., in press) and are locally highly deformed.

Several back-thrusts extend to the surface, and the hypothetical trace of two back-thrusts is shown in the model (Fig. 11). Back-thrusts, interpreted northwest of the Horton Group outcrop ("abt" in Fig. 11), occur within the Windsor Group as suggested in Figure 7. One back-thrust cuts into the Horton Group and may extend along the axis of the Mull River Syncline or may swing in a more northerly direction. This back-thrust and the accompanying anticline in the Horton Group, which is actually a roll-over into the thrust (fore limb thrust?), are seen in Figure 6. Our interpretation (Fig. 11) suggests a structural link between the Horton Group anticline and the back-thrust. Norman (1935) noted that the pre-Carboniferous basement, and its associated cover (i.e., the Horton Group), formed dome-like structures. They may be the result of a complex fault and fold pattern, resulting from movement on deep, northwest vergent, basement involved thrusts and antithetic back-thrusts.

The Mull River structure is just one example of several northwest vergent thrusts that were interpreted in this study (Fig. 5). Thrust faults were also recognized near the centre and in the southern part of St. Georges Bay, and a thrust component is suggested on the Glenroy Fault by gravity data. The widespread distribution of thrusts in the AntigonishMabou Subbasin may be indicative of a regional compressional event. The timing of such an event is not known at present and requires further study. Seismic studies of the basin fill may help constrain the time of thrusting.

\section{Conclusions}

Interpretation of petroleum industry seismic reflection data shows that the Carboniferous Antigonish-Mabou Subbasin is deep and structurally complex. The time structure map, constructed using a seismic event (reflector ' $A$ ') at the base of the Windsor Group, delineates the deepest part of the subbasin $(5600 \mathrm{~m})$ in the north-central area of St. Georges Bay.

A number of new faults have been interpreted from the geophysical data. These include: the Southside Harbour Fault on the west side of the bay, with a downthrow to the east of $600 \mathrm{~m}$; the Judique Fault on the east side of the bay with a downthrow to the west of $3200 \mathrm{~m}$; and a complex fault system (Cape Jack and Long Point faults) on the south side of the bay.

Evidence for hitherto unsuspected thrusts is provided by both the seismic data and gravity profile interpretation. Hidden, or blind, thrusts (Thompson, 1981) have been interpreted in the Mull River area from seismics, borehole data and geological mapping. Widespread thrust faulting has been interpreted from seismic data in southern St. Georges Bay. The Glenroy Fault, in the southwestern part of the subbasin, has also been interpreted as a thrust from gravity modelling.

In all cases, the main movement along the thrusts has been to the northwest. In some areas (i.e., Mull River), backthrusts have developed and have transferred the fault movement to the surface. Rocks in the hanging wall of the basal thrust have acted as a "plow" moving to the northwest, which has wedged beneath and folded upwards part of the Windsor Group and the overlying strata. Dishamonic folds involving Windsor Group and younger rocks may have developed in response to the thrust faulting. In this way, complex structures at depth have been related to the northeast striking open synclines and faults (intruded by Windsor Group evaporites), previously delineated by seismic profiling (Durling et al., 1995) and onshore geological mapping.

\section{Acknowledgements}

We wish to thank Chevron Canada Resources for providing access to digital seismic data offshore and migrated paper copies of their seismic data onshore, and Nova Scotia Research Foundation Corporation for the opportunity to publish the results of the gravity modelling. We appreciate the help and support of F. Marillier and K. Coflin, who also gave early reviews of the paper. A. Jackson gave technical assis- 


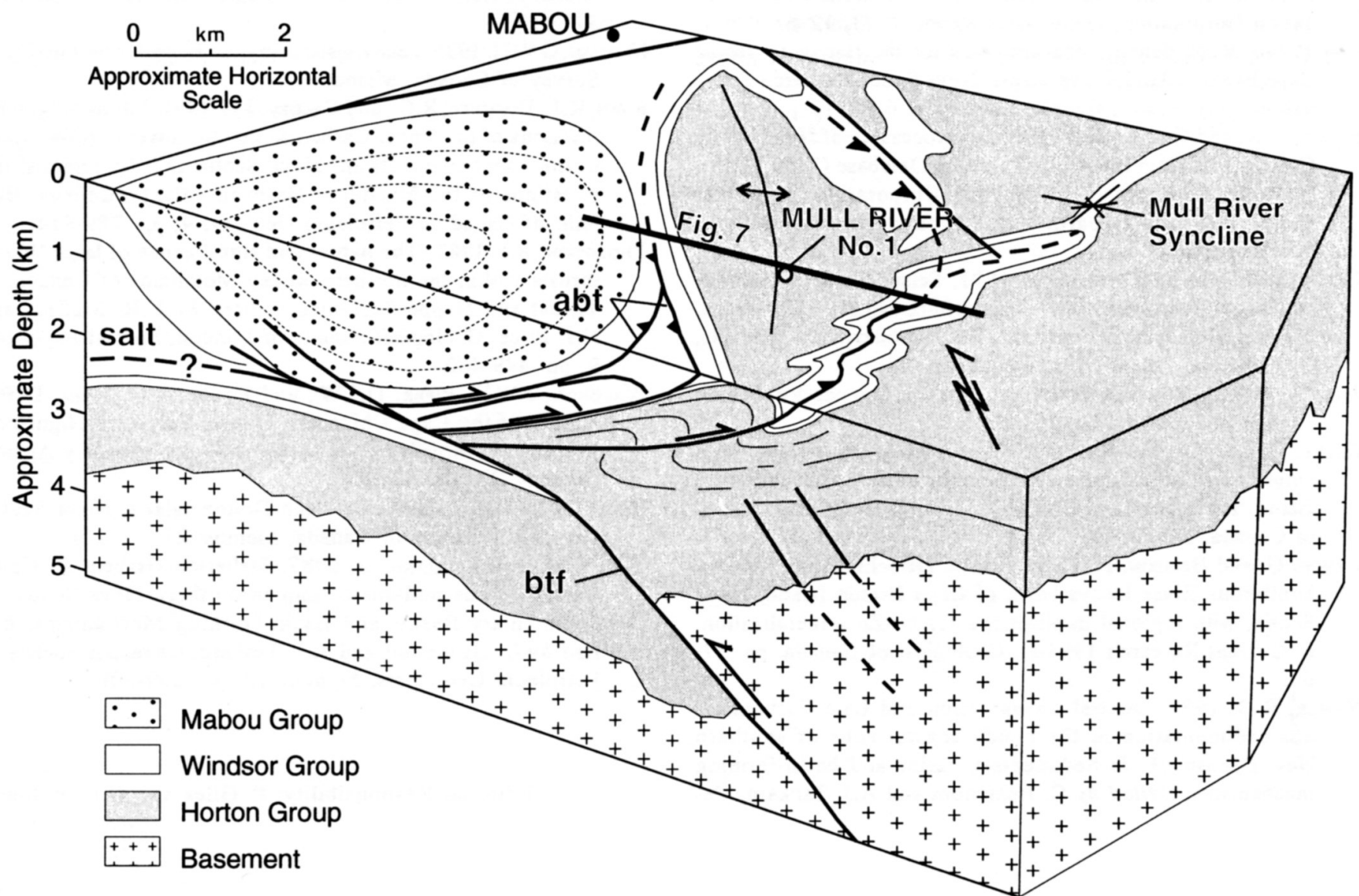

Fig. 11. Schematic block diagram for the Mull River area. See text for discussion. Surface geology taken from Norman (1935) and the subsurface geology is based on seismic lines $62 \mathrm{Y}$ (Fig. 7) and 37 (Fig. 6). Abbreviations: abt $=$ additional back-thrust; btf $=$ basal thrust fault. Note that the vertical scale is based on a constant seismic velocity of $4000 \mathrm{~m} / \mathrm{s}$. As such, the vertical scale is subject to unknown errors and is therefore approximate.

tance for the seismic workstation and P.S. Giles advised on the geology of the area. We thank the journal reviewers, J.W.F. Waldron and A.C. Grant for their perceptive comments and recommendations which we have incorporated to improve the manuscript.

BENSON, D.G. 1970. Notes to accompany geological maps of Antigonish and Cape George map-areas, Nova Scotia. Geological Survey of Canada, Paper 70-8, 5 p.

Blanchard, J.E. 1956. Preliminary Report of a Negative Gravity Anomaly at St. Andrew's, Antigonish County, Nova Scotia. Nova Scotia Research Foundation Corporation. Geophysics, Report 2-56, 3 p.

Boenner, R.C. 1986. Salt and Potash Resources in Nova Scotia. Nova Scotia Department of Mines and Energy, Bulletin 5, $346 \mathrm{p}$.

Boenner, R.C. and Giles, P.S. 1993. Geology of the Antigonish Basin, Antigonish County, Nova Scotia. Nova Scotia Department of Natural Resources, Mines and Energy Branches, Memoir 8, 109 p.

BRoOME, J. 1986. MAGRAV2: An interactive magnetics and gravity modelling program for IBM-compatible microcomputers. Geological Survey of Canada, Open File Report 1334, 83 p. Revised 1989.

CURRIE, K.L. 1977. A note on post-Mississippian thrust faulting in northwestern Cape Breton Island. Canadian Journal of Earth Sciences, 14, pp. 2937-2941.
Davis, D.M. and Engelder, T. 1985. The role of salt in fold-andthrust Belts. Tectonophysics, 119, pp. 67-88.

DURLING, P. 1996. A seismic reflection study of the Fountain Lake Group in the Scotsburn Anticline area, northern Nova Scotia. In Current Research 1996-D, Geological Survey of Canada, pp. 47-53.

Durling, P. and Marillier, F. 1993a. Structural elements of the Magdalen Basin, Gulf of St. Lawrence, from seismic reflection data. In Current Research, Part D, Geological Survey of Canada, Paper 93-1D, pp. 147-154.

--.- 1993b. Tectonic setting of Middle Devonian to Lower Carboniferous rocks in the Magdalen Basin. Atlantic Geology, 29, pp. 199-217.

Durling, P., Howells, K., and Harvey, P. 1995. The near surface geology of St. Georges Bay, Nova Scotia: implications for the Hollow Fault. Canadian Journal of Earth Sciences, 32, pp. 603-613.

Giles, P.S., Hein, F.J., and Allen, T.L. In press. Bedrock Geology of Port Hood-Lake Ainslie (11K04, 11K03, 11F13), Cape Breton Island, Nova Scotia. Geological Survey of Canada, Open File.

Gussow, W.C. 1953. Carboniferous stratigraphy and structural geology of New Brunswick, Canada. Bulletin of the American Association of Petroleum Geologists, 37, pp. 1713-1816.

Hacquebard, P.A., Gillis, K.S., and Bromley, D.S. 1989. Re-evaluation of the coal resources of western Cape Breton Island. Nova Scotia Department of Mines and Energy, Paper 89-3, 47 p. HowELLS, K. 1973a. Some rock density measurements from northern 
Cape Breton Island, Nova Scotia. Nova Scotia Research Foundation Corporation, Geophysics Report 4-73, 12 p.

....- 1973b. Rock density measurements for the Baddeck area of Cape Breton Island, Nova Scotia. Nova Scotia Research Foundation Corporation, Geophysics Report 6-73, 13 p.

Howells, K. and Clarke, D.E. 1995. Reprocessing of Nova Scotia Gravity data from the NSRFC Gravity Database (1952-1988). Nova Scotia Research Foundation Corporation, Report 195. Nova Scotia Department of Natural Resources, Open File Report.

Howells, K. and Roulston, B.V. 1991. Seismic reflection interpretation of evaporites in the Moncton Subbasin, New Brunswick. Abstract, 1991 Atlantic Geoscience Society Colloquium, Wolfville, Nova Scotia. Atlantic Geology, 27, p. 54.

Jenyon, M.K. 1986. Salt Tectonics. Elsevier Science Publishing Company, Incorporated, $191 \mathrm{p}$.

Kelly, D.G. 1967. Baddeck and Whycocomagh map-areas: with emphasis on Mississippian stratigraphy of central Cape Breton Island, Nova Scotia $(11 \mathrm{~K} / 2$ and $11 \mathrm{~F} / 14)$. Geological Survey of Canada, Memoir 351, 65 p.

Lynch, G. and Brisson, H. 1994. Ainslie Detachment in the Carboniferous River Denys basin of Cape Breton Island, Nova Scotia, with regional implications for $\mathrm{Pb}-\mathrm{Zn}$ mineralization. In Current Research 1994-D, Geological of Canada, pp. 5762.

Nance, R.D. 1987. Dextral transpression and Late Carboniferous sedimentation in the Fundy coastal zone of southern New Brunswick. In Sedimentary basins and basin-forming mechanisms. Edited by C. Beaumont and A.J. Tankard. Ca- nadian Society of Petroleum Geologists, Memoir 12, pp. 363 377.

Norman, G.W.H. 1935. Lake Ainslie map-area, Nova Scotia. Geological Survey of Canada, Memoir 177.

RYAN, R.J., BOEHNER, R.C., and CALDER, J.H. 1991. Lithostratigraphic revisions of the Upper Carboniferous to Lower Permian strata in the Cumberland Basin, Nova Scotia and the regional implications of the Maritimes Basin in Atlantic Canada. Bulletin of Canadian Petroleum Geology, 4, pp. 289-314.

THOMPSON, R.I. 1981. The nature and significance of large 'blind' thrusts within the northern Rocky Mountains of Canada. In Thrust and Nappe Tectonics. Edited by K.R. McClay and N.J. Price. Geological Society of London, Special Paper No. 9, pp. 449-462.

Waldron, J.W.F., Piper, D.J.W., and Pe-Piper, G. 1989. Deformation of the Cape Chignecto Pluton, Cobequid Highlands, Nova Scotia: thrusting at the Meguma-Avalon boundary. Atlantic Geology, 25, pp. 51-62.

Weeks, L.J. 1954. Southeast Cape Breton Island, Nova Scotia. Geological Survey of Canada, Memoir 277, 112 p.

Yeo, G.M. and Ruixiang, G. 1987. Stellarton Graben: an Upper Carboniferous pull-apart basin in northern Nova Scotia. In Sedimentary Basins and Basin-Forming Mechanisms. Edited by C. Beaumont and A.J. Tankard. Canadian Society of Petroleum Geologists, Memoir 12, pp. 299-309.

Editorial Responsibility: P. Giles and G.L. Williams 